\title{
Incidence of cardiac malformations at birth and later, and neonatal mortality
}

\author{
Maurice Campbell \\ From the Cardiac Department, Guy's Hospital, and the National Heart Hospital, London
}

Malformations of the heart are found in about 8 of every Iooo births. In addition, about 4 of every Iooo births have bicuspid aortic valves, but they are rarely recognized early in life. Apart from these, ventricular septal defect is much the commonest malformation, forming about 30 per cent of all others. Probably small ventricular septal defects and bicuspid aortic valves are common because they have few drawbacks during the reproductive period so are hardly checked by natural selection. Atrial septal defect and persistent ductus arteriosus come next, each forming about Io per cent. Pulmonary stenosis and aortic coarctation each form about 7 per cent. Aortic stenosis and Fallot's tetralogy form about 6 per cent and transposition of the great trunks 4 per cent. These 8 malformations are responsible for 80 per cent of the total, but many less common ones have been listed.

The neonatal mortality is so high that the incidence of all cardiac malformations is soon reduced to about half its incidence at birth. The mortality rates are strikingly different. They are about 90 per cent for transposition and truncus, reducing these to insignificant proportions in older children. They are between 50 and 60 per cent for aortic coarctation, because most with preductal coarctation die early, for Fallot's tetralogy, and for those with multiple malformations. For other common malformations they are probably higher for ventricular and atrial septal defects (both about 36\%), than for aortic stenosis (about 29\%) and lower for pulmonary stenosis $(24 \%)$ and persistent ductus arteriosus (23\%). The prominence of ventricular septal defect at birth is reduced by the large number that close spontaneously, and this applies also to persistent ductus arteriosus but to a lesser extent.

The observed incidence in schoolchildren and in older children and young adults is described. This agrees reasonably well with the figures calculated from the incidence at birth and the differential mortality, neonatal and during the first two decades.

At birth, bicuspid aortic valves, aortic stenosis, coarctation, and most cyanotic conditions have a higher male incidence which continues or increases at older ages. Only persistent ductus arteriosus has a higher female incidence at birth and it too increases with age, but adults with atrial septal defect and ventricular septal defect show an increasing female incidence. Only pulmonary stenosis shows no difference between the sexes.

Some short comments on malformations in general should show cardiac ones in clearer prospective. Lamy and Frezal (I960) reviewed I9 series from several European countries, the United States, and Japan, all dealing with several thousand subjects. They found the total incidences of all malformations fairly constant but those of some individual ones varied considerably. Thus polydactyly is much commoner in several African races; and anencephaly is commoner in Scotland than in England, commoner in England than in most of Europe, and commoner Received 23 August 1972. in Caucasian races than in Negroes. Some incidences varied widely, the highest figure being ro times as large as the lowest; while for achondroplasia, more easily recognized, it was only twice as much $(0.025$ against $0.013 \%$ ).

The incidence of all major malformations was generally about 2 per cent for those recognized at birth but higher for series observed and re-examined after a year or more. Many were collected in 1930-50 and all cardiac malformations were reported as only 2.4 per thousand. But it was only very gradually that interest in and ability to diagnose 
TABLE I Incidence of major malformations per 1000 births

After McKeown and Record (1960) and Carter (196I)

\begin{tabular}{lll}
\hline Malformation & \multicolumn{2}{l}{ Incidence per 1000 births } \\
\cline { 2 - 3 } & $\begin{array}{l}\text { Range of } \\
\text { three series }\end{array}$ & $\begin{array}{l}\text { Average } \\
\text { incidence }\end{array}$ \\
\hline Anencephalus & $0 \cdot 6-2 \cdot 0$ & $1 \cdot 6$ \\
Spina bifida & $0 \cdot 3-3 \cdot 0$ & $2 \cdot 0$ \\
Hydrocephalus & $0 \cdot 5-2 \cdot 6$ & $1 \cdot 7$ \\
Major central nervous system & & \\
malformations & - & $5 \cdot 3$ \\
Cardiac malformations & $4 \cdot 2-8 \cdot 5$ & $6 \cdot 0$ \\
Hare-lip and cleft palate & $1 \cdot 6-3 \cdot 0$ & $2 \cdot 1$ \\
Dislocation of hip & $0 \cdot 7-7 \cdot 1 \ddagger$ & $2 \cdot 4$ \\
Talipes & $1 \cdot 4-4 \cdot 4$ & $3 \cdot 9$ \\
Mongolism & $0 \cdot 9-1 \cdot 9$ & $1 \cdot 6$ \\
Congenital pyloric stenosis & $2 \cdot 0-3 \cdot 0$ & $2 \cdot 7$ \\
\hline Total major malformations & - & $24 \cdot 0$ \\
\hline
\end{tabular}

* The three series were from Birmingham, England, adjusted for children up to 5 years of age, and from America and Japan, adjusted up to I year of age.

t The Japanese series was given less weight than the other two in this column for comparison with American and British families.

¥ This unusually high incidence was in the Japanese series.

them spread, mainly under the influence of Helen Taussig (1936) and James Brown (1939). More modern estimates are shown in Table I after McKeown and Record (1960) and Carter (196I) which is based on three series from England, America, and Japan. In reaching average figures shown in the last column less weighting has been given to Japanese figures for comparisons with British and American families. All major malformations form 24 per thousand births and malformations of the heart form one-quarter of these, i.e. 6 per thousand.

Smithells (1968), among 80,640 livebirths registered at Liverpool, found a higher incidence of all malformations (29.9 per 1000), and a higher one for those of the central nervous system (7.I per I000) but lower for those of the heart ( 5 per 1000). Combining these four series, all malformations are just over 25 per 1000 births. One cannot say if malformations of the heart or central nervous system are most common (both 5.75 per 1000) but they are certainly the two largest groups, between them responsible for nearly half all major malformations.

\section{Incidence of malformations in miscarriages and stillbirths}

Neel (1958) wrote that since Mall's work in 1917 opinion has been that 20 to 25 per cent of miscarriages during the first trimester have major defects. In his Japanese series, Neel found ro per cent of stillbirths had major malformations compared with 3 per cent of living children.

McIntosh et al. (1954) in 6053 deliveries found 5 per cent miscarriages, $\mathrm{I} \cdot 8$ per cent stillbirths, and I.8 per cent neonatal deaths. The incidence of all malformations was 13 per cent in stillbirths, 23 per cent in those stillborn at the normal time of delivery, and 29 per cent in infants dying during the first month compared with 7 per cent among those surviving. Richards et al. (I955a, b), reporting on cardiac aspects of this group, found cardiac malformations in 5 per cent of stillbirths and in 10 per cent of neonatal deaths, compared with 0.6 per cent among those who survived. The high incidence of cardiac malformations among stillbirths is now generally accepted, and Mitchell, Korones, and Berendes (197I) found they formed 7.3 per cent, nearly 1o times as many as in livebirths. We still need to know more about their importance in miscarriages and about individual cardiac malformations.

\section{Incidence of all cardiac malformations}

Cardiac malformations are taken to include persistent ductus arteriosus and aortic coarctation. Lamy and Frezal (1960) found their reported incidence as low as 2.4 per 1000 births. Even MacMahon, McKeown, and Record (1953), the pioneers of modern methods, increased it only to $3 \cdot 2$ per 1000 after adjusting for diagnoses missed at first and made during subsequent years.

Harris and Steinberg (1954) found it to be 6.8 and McIntosh et al. (1954) 6.5 per 1000, both in America; Carlgren (1959) 6.4 in Sweden, and Mustacchi, Sherins, and Miller (1963) 5.9 per 1000 in San Francisco. Hay (1966) at Liverpool found a lower incidence of 4.7 per 1000 , or rather more because new examples were being found as children were followed longer. He excluded 134 with doubtful or functional systolic murmurs but some may have been caused by small ventricular septal defects that were closing. If all were excluded, his figure would be 6.3 per 1000. When first writing about this (Campbell, 1968d) I accepted an incidence of 6 per rooo on the close agreement of these series and shown in Table $\mathrm{I}$.

Watson (1972) thinks the incidence 8, or probably 10 per 1000, basing this on four recent series Landtman (1965) at Helsinki 8.0, Kerrebijn (1966) 
TABLE 2 Percentage incidence of different malformations at birth

\begin{tabular}{|c|c|c|c|c|c|c|c|c|}
\hline & $\begin{array}{l}\text { MacMahon } \\
\text { et al. (1953) }\end{array}$ & $\begin{array}{l}\text { Carlgren } \\
(1959)\end{array}$ & $\begin{array}{l}\text { Carlgren } \\
\text { (1969) }\end{array}$ & $\begin{array}{l}\text { Hay } \\
(1966)\end{array}$ & $\begin{array}{l}\text { Rose et al. } \\
\quad(1964)\end{array}$ & $\begin{array}{l}\text { Michaëlsson } \\
\text { (1964) }\end{array}$ & $\begin{array}{l}\text { Mitchell } \\
\text { et al. }(1971)\end{array}$ & Mean \\
\hline $\begin{array}{l}\text { Ventricular septal defect } \\
\text { Atrial septal defect } \\
\text { Persistent ductus arteriosus } \\
\text { Pulmonary stenosis } \\
\text { Coarctation } \\
\text { Aortic stenosis } \\
\text { Fallot's tetralogy } \\
\text { Transposition } \\
\text { Truncus } \\
\text { Tricuspid atresia } \\
\text { All others }\end{array}$ & $\begin{array}{l}23 \\
11 \\
16 \cdot 5^{\star} \\
3 \cdot 5 \\
8 \cdot 5 \\
1 \\
8 \\
11 \\
4 \cdot 5 \\
-13\end{array}$ & $\begin{array}{r}31 \cdot 5 \\
6 \cdot 6 \\
8 \cdot 5 \\
5 \cdot 5 \\
10 \cdot 5 \\
7 \cdot 2 \\
5 \cdot 5 \\
7 \cdot 7 \\
1 \cdot 5 \\
1 \cdot 5 \\
14\end{array}$ & $\begin{array}{l}43 \\
7 \cdot 5 \\
8 \cdot 5 \\
5 \\
7 \\
7 \\
5 \\
6 \cdot 5 \\
1 \cdot 5 \\
1 \cdot 5 \\
7 \cdot 5\end{array}$ & $\begin{array}{l}34 \\
11 \cdot 7 \\
7 \cdot 7 \\
8 \\
5 \cdot 3 \\
4 \cdot 2 \\
5 \cdot 9 \\
5 \cdot 6 \\
1 \cdot 6 \\
1 \cdot 3 \\
14 \cdot 7\end{array}$ & $\begin{array}{l}31 \\
11 \\
7 \\
11 \\
3 \cdot 5 \\
8 \cdot 5 \\
8 \\
2 \cdot 5 \\
- \\
1 \\
15 \cdot 5\end{array}$ & $\begin{array}{r}22 \cdot 5 \\
9 \cdot 5 \\
12 \cdot 5 \\
6 \\
6 \\
6 \\
5 \\
3 \cdot 5 \\
\frac{-}{29}\end{array}$ & $\begin{array}{l}29 \\
11 \cdot 5 \\
7 \cdot 5 \\
9 \cdot 5 \\
6 \cdot 5 \\
3 \cdot 5 \\
3 \cdot 5 \\
2 \cdot 5 \\
2 \\
? \\
24 \cdot 5\end{array}$ & $\begin{array}{r}30 \cdot 5 \\
9 \cdot 8 \\
9 \cdot 7 \\
6 \cdot 9 \\
6 \cdot 8 \\
6 \cdot 1 \\
5 \cdot 8 \\
4 \cdot 2 \\
2 \cdot 2 \\
1 \cdot 3 \\
16 \cdot 5\end{array}$ \\
\hline $\begin{array}{l}\text { No. of cases } \\
\text { Total births (thousands) }\end{array}$ & $\begin{array}{l}372^{\star} \\
199\end{array}$ & $\begin{array}{r}361 \\
58\end{array}$ & $\begin{array}{r}439 \\
58\end{array}$ & $\begin{array}{r}316 \\
80\end{array}$ & - & $\begin{array}{r}363 \\
26\end{array}$ & $\begin{array}{r}459 \\
56\end{array}$ & $\begin{array}{r}2310 \dagger \\
476 t\end{array}$ \\
\hline
\end{tabular}

* 16.5 per cent is probably too high because this was the only operation performed frequently then and so used as a method of diagnosis. There were also $26 \mathrm{I}$ undiagnosed malformations.

$t$ These give the total number of cardiac malformations and of all births.

at Leiden $8 \cdot 25$, Carlgren (1969) at Gothenburg 7.7, and Mitchell et al. (197I) at I2 centres in U.S.A. also $7 \cdot 7$ per 1000 .

\section{Individual cardiac malformations at birth}

For accurate estimates of incidence, infants must be examined and followed by cardiologists for some years because decisive signs may be delayed. Aortic and pulmonary stenosis, coarctation, and atrial septal defect seem likely to be missed. Before children reach ordinary paediatric departments many will have died in the first weeks of life.

MacMahon et al. (1953) first made this attempt on a sufficiently large scale, following the children for some years and studying the records of 633 children born with cardiac malformations in 1940-49 to mothers domiciled in Birmingham. Among 372 where a diagnosis was made, ventricular septal defect was commonest ( $23 \%$ of total). Next came persistent ductus (16\%); transposition of the great trunks and atrial septal defect, both about II per cent; aortic coarctation and Fallot's tetralogy, both under 9 per cent; truncus arteriosus, nearly 5 per cent; pulmonary stenosis, less than 4 per cent, and aortic stenosis only I per cent: all other conditions made up 13 per cent (Table 2).

The figures of McIntosh et al. (1954) were dealt with by Richards et al. (1955a, b). Their intimate knowledge of the pregnancies and births provided useful information on many aspects, but the small numbers showed only that septal defects, persistent ductus, and Fallot's tetralogy were common. Prob- ably no small group can collect enough cases from their own obstetric experience.

Carlgren (1959) chose Gothenburg, a small town where he could follow most children who survived. Among 369 with cardiac malformations during 1941-50, the figure of 322 with reasonably certain diagnoses $(87 \%)$ was much higher than that of MacMahon et al. (59\%) and his follow-up (7-16 years) longer than theirs (3-II years). He too found ventricular septal defect most frequent (31\%). Next came persistent ductus, atrial septal defect, and aortic coarctation (each between 9 and II \%); then transposition ( $7 \%$ ), aortic stenosis (6\%), and pulmonary stenosis $(5.6 \%)$; then Fallot's tetralogy with nearly 5 per cent; and finally truncus arteriosus and tricuspid atresia, each with $\mathrm{I} \cdot 5$ per cent: rather over II per cent included all other malformations.

Hay (1966), among children born at Liverpool, found 5 IO with cardiac malformations. Excluding those with murmurs thought to be functional or of doubtful significance, he also found ventricular septal defect most common ( $34 \%$ ), then atrial septal defect including some ostium primus defects (II.7\%), then pulmonary stenosis ( $8 \%$ ) and persistent ductus arteriosus $(7 \cdot 7 \%)$, then Fallot's tetralogy $(5.9 \%)$, transposition $(5.6 \%)$, and coarctation $(5 \cdot 3 \%)$, and then aortic stenosis $(4.2 \%)$.

Details have been added in Table 2 from Michaëlsson (1964), Carlgren (1969), Mitchell et al. (197I), and Rose, Boyd, and Ashton (1964) from Toronto. The first six series represent 2521 infants with cardiac malformations among 470,000 births. 
Excluding bicuspid aortic valves, ventricular septal defects are certainly commonest, forming 30.5 per cent of all. Hoffman (1968) paid special attention to their incidence and found it to be $1 \cdot 6$ per 1000 of all births. My percentage of the higher total incidence would now make it 2.4 per 1000 . Six of the estimates were between 22.5 and 34 per cent, but Carlgren's 1969 estimate (43\%) included many infants with small defects that often closed, mainly during their first year.

This, I think, will become generally accepted and ventricular septal defect will need subdivision into 'small' and 'larger' defects. Probably small ventricular septal defect and bicuspid aortic valves are common because, unlike other cardiac malformations, they have few drawbacks during the reproductive period and so are hardly checked by natural selection.

There is no agreement whether atrial septal defect $(9.8 \%)$ or persistent ductus arteriosus $(9.7 \%)$ should come next, but almost certainly they occupy second and third places though this was not found in all series of Table 2. MacMahon's estimate for persistent ductus arteriosus is almost certainly too high, as this was the only condition being operated on then and so more likely to be recognized. Without this estimate, persistent ductus arteriosus would not be as close to atrial septal defect.

Pulmonary stenosis $(6.9 \%)$ and aortic coarctation $(6.8 \%)$ come fourth and fifth. Almost, but not quite certainly, these two are commoner than the next two, but the gap was narrowed by Rose's estimate, the last to be added. Hay's estimate for pulmonary stenosis was double that for coarctation but MacMahon's estimates were the reverse which emphasizes the uncertainties. The relative proportions with valvar and subvalvar pulmonary or aortic stenosis are given in Campbell (1968b, 1969).

Aortic stenosis $(6 \cdot 1 \%)$ and Fallot's tetralogy $(5.8 \%)$ are sixth and seventh. The former is impossible to assess accurately at first because it is a question of semantics whether subjects whose bicuspid valves later cause aortic stenosis should be included. MacMahon's very low estimate was omitted in calculating a mean, because in 1940-49 congenital aortic stenosis was so rarely recognized.

Transposition of the great trunks $(4.2 \%)$ is undoubtedly eighth, well below the two previous and well above the next two conditions. Most series included truncus arteriosus $(2 \cdot 2 \%)$ and tricuspid atresia $(1 \cdot 3 \%)$.

The remaining 16.5 per cent were classified as miscellaneous, some with two malformations where neither was obviously most important and some with less common malformations. The eight commoner conditions (excluding persistent truncus and tricuspid atresia) account for 84 per cent of all cardiac malformations at birth, or rather more as pulmonary stenosis and coarctation, and perhaps aortic stenosis and atrial septal defect, are sometimes missed at first.

Maude Abbott in her Atlas of Congenital Cardiac Disease (1936) pointed out that reported necropsies did not give a true picture of incidence. They did, however, find the eight commoner malformations but in a very different order. Necropsies of Fallot's tetralogy, persistent ductus arteriosus, and coarctation were reported most often ( $8-12 \%$ each); then ventricular septal defect and transposition (5-6\%); and then pulmonary stenosis, atrial septal defect, and aortic stenosis $(2-4 \%)$. These 8 malformations accounted for over half of all reported.

Landtman (I97I), among necropsies in a children's hospital, found the commonest conditions were ventricular septal defect and transposition (each 13\%), and then atrial septal defect, coarctation, and truncus arteriosus (each about $9 \%$ ).

The scanty evidence available about other races suggests that they have similar incidences for most cardiac malformations. Muir (1960) at Singapore found 4II subjects with cardiac malformations at unselected necropsies, mostly of Chinese. There were similar proportions of the eight commoner cardiac malformations. Caddell and Connor (1966) in Uganda and Gupta and Antia (1967) in Nigeria found ventricular septal defect and persistent ductus arteriosus to be the most common malformations at birth and the other 6 commonest ones to be represented though they had only 59 cases in all. Morton and Huhn (1966) found no difference between nonwhites, Hispanos, and other whites in American schoolchildren; and Schrire (1963) in South Africa found the same total incidence in white, Capecoloured, and Bantu patients.

\section{Less common malformations}

Few less common malformations form more than I per cent of the total. Eisenmenger's complex formed 3 per cent of Wood's (1956) series, but is included with ventricular septal defect because it is a functional state to which many with large defects pass. Again I have arranged them in order, but here more for convenience than as a precise order of frequency.

Approximate incidences, recorded by several authors quoted, are shown in Table 3. Six conditions were included by most of them. (I) Truncus arteriosus $(I-4 \%)$ and (2) tricuspid atresia $(I-2 \%)$ have been shown in Table 2. (3) Dextrocardia $(\mathrm{I}-2 \%)$. Carlgren divided his into equal numbers of cyanotic and acyanotic forms, and there was one example of isolated laevocardia in Hay's series. My 
TABLE 3 Some less common malformations of the heart

\begin{tabular}{|c|c|c|}
\hline & $\begin{array}{l}\text { Percentage } \\
\text { incidence }\end{array}$ & Comment \\
\hline Persistent truncus arteriosus & $1-4$ & Included in earlier tables; uncommon after infancy \\
\hline Tricuspid atresia & $1-3$ & Included in earlier tables \\
\hline Dextrocardia and isolated laevocardia & $1-2$ & Excluding situs inversus with a normal heart \\
\hline Aortic atresia & $\mathrm{I}-\mathbf{2}$ & All fatal in early weeks; see mitral atresia \\
\hline Mitral atresia and undeveloped left heart & $\overline{\mathbf{c}} \mathbf{I}$ & Landtman's mitral and aortic atresia were 9 per cent $\dagger$ \\
\hline Common atrioventricular canal & $>\mathbf{I}$ & Hard to assess because many lists contain common group \\
\hline$\{$ Common ventricle & $<\mathbf{I}$ & of cor biloculare and triloculare (see text) \\
\hline Common atrium & $<\mathrm{I}$ & \\
\hline Ebstein's syndrome & $\overline{\mathbf{c}} \mathbf{I}$ & \\
\hline Congenital heart block & $\overline{\mathbf{c}} \mathbf{I}$ & \\
\hline Idiopathic cardiac hypertrophy & $\overline{\mathbf{c}} \mathbf{I}$ & \\
\hline Pulmonary atresia without ventricular septal defect & $<\mathbf{I}$ & $\begin{array}{l}\text { Those with ventricular septal defect often included with } \\
\text { Fallot's tetralogy, but better not so }\end{array}$ \\
\hline Anomalous pulmonary venous drainage, total & $<\mathrm{I}$ & $\begin{array}{l}\text { Partial anomalous pulmonary venous drainage generally } \\
\text { with atrial septal defect }\end{array}$ \\
\hline Idiopathic pulmonary dilatation & $<\mathbf{I}$ & Not generally included but sometimes I per cent \\
\hline Vascular ring & $<\mathbf{I}$ & $\begin{array}{l}\text { Not generally included but over I per cent in Hay's } \\
\text { series }\end{array}$ \\
\hline Fibroelastosis & $<\mathbf{I}$ & $\begin{array}{l}\text { Not generally included but I per cent in Keith et al. (and } \\
4 \% \text { in Landtman } \dagger \text { ) }\end{array}$ \\
\hline
\end{tabular}

*This refers to the percentage incidence among subjects with cardiac malformations at birth.

t Landtman's (I97I) series were infants admitted to hospital, so increase serious conditions.

own experience puts these higher; among older cyanotic children, dextrocardia as over 2 per cent and isolated laevocardia as I per cent. (4) Aortic atresia (I-2\% of some series) and (5) mitral atresia (about $\mathrm{I} \%$ ) have such a bad outlook that Landtman (197I) found his group of hypoplastic left heart syndrome formed 9 per cent of infants dying in hospital, more than half in the first week. (6) Common atrioventricular canal formed 2 per cent of Hay's series. Because several authors list 'cor biloculare and cor triloculare', it is not easy to assess their incidence. Cor biloculare has a precise meaning: common $\mathrm{AV}$ canal, common atrium, and common ventricle. But cor triloculare without further definition has no precise meaning and is better avoided. These three conditions together account for over 2 per cent (Table 3), but more than this if the many examples among those with dextrocardia and isolated laevocardia are also included. Many of these too were included in Abbott's recropsy series: dextrocardia $(3 \%)$, cor biloculare and triloculare $(<3 \%)$, truncus arteriosus $(2 \%)$, tricuspid atresia $(<2 \%)$, and aortic atresia $(1 \%)$.

Next come five conditions mentioned by several but not by all authors and generally under I per cent. These are (7) Ebstein's syndrome, (8) heart block, and (9) idiopathic cardiac hypertrophy or familial cardiomyopathy, which becomes more frequent later; then (IO) pulmonary atresia without a ventricular septal defect: other cases of pulmonary atresia were included with Fallot's tetralogy in several series, though now that surgical treatment has become so important, they should be listed separately; and Wood puts this group alone as over I.5 per cent. Altogether it sometimes formed nearly 3 per cent. Then (II) total anomalous pulmonary venous drainage: the partial form of this is sometimes listed under atrial septal defect, which generally accompanies both forms. It was about 2 per cent of perhaps the most accurate series of incidence at birth, that of Hay (1966).

Finally there are three conditions included only by a few authors. (12) Idiopathic pulmonary dilatation formed I per cent of Carlgren's series; (13) vascular rings formed $I \cdot 7$ per cent of Hay's series; and (14) fibroelastosis formed nearly 2 per cent in the series of Hay and over $I$ per cent in that of Keith, Rowe, and Vlad. In general these probably form about $\mathrm{I} \cdot \mathrm{O}$ per cent.

Some rarer malformations seem worth listing though none can have an incidence of more than between $I$ in 200 to 500 . They are defects of the pericardium, cor triatriatum, myocardial changes with Friedreich's ataxia and other inherited nervous conditions, defects of the aortic septum, aneurysm of the sinus of Valsalva, stenosis of a pulmonary artery, and pulmonary-coronary arterial fistula. Single examples of some of these are mentioned by our authors. With further experience, a few of these may prove more common. 
There are, however, some common malformations that are rarely listed. Bicuspid aortic valves have not been included by any of our authors. They cannot be recognized with certainty in infancy but are common and may cause aortic stenosis or regurgitation or be the site of bacterial endocarditis. Curiously, their incidence was studied early and was found to be about I in 260 in all hospital necropsies (Wauchope, 1928). Their high incidence of 4 in every 1000 births (Campbell, 1968a), though not recognized till later, would increase all cardiac malformations from 8 to 12 per 1000 births. Bicuspid pulmonary valves are not uncommon with pulmonary stenosis, but much less common alone.

Abnormalities in distribution of coronary arteries and of aortic arch branches are fairly common. A right-sided aortic arch occurs in a quarter of those with Fallot's tetralogy and in more with truncus arteriosus, and occasionally as a sole lesion. A persistent left superior vena cava was present in 3 per cent of a large series of children with cardiac, mainly cyanotic, malformations (Campbell and Deuchar, 1954). The subject is complex and some of my simplifications may seem unjustified, but without them my paper would be nearly as long as the relevant papers combined.

\section{Noenatal mortality in cardiac malformations}

Mortality is very high especially in the first year,

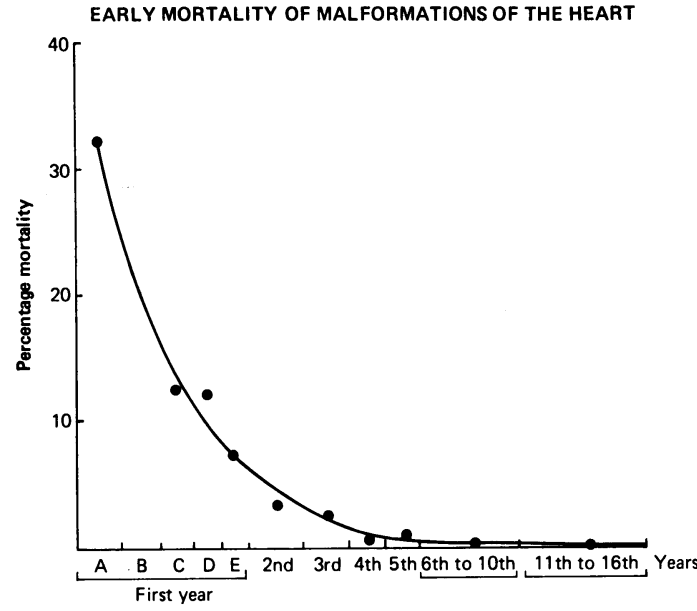

FIG. Percentages dying at various ages up to 16 years among 777 patients of Landtman (197I). $(A)$ First week $(32.5 \%) ;(B)$ rest of first month $(20.3 \%) ;(C)$ second and third months $(13 \%) ;(D)$ fourth to sixth months $(12.5 \%) ;(E)$ seventh to twelfth months $(7.5 \%)$, 85.8 per cent in first year. Second and third years $(6.5 \%$, shown as 3.8 and $2.7 \%)$; fourth and fifth years $(2.0 \%$, shown as $I$ and $I \%)$; sixth to tenth years ( $3.1 \%$, shown as $0.6 \%$ each year); eleventh to sixteenth years $(2.6 \%$, shown as $0.4 \%$ each year $)$.

TABLE 4 Neonatal mortality of different cardiac malformations

Percentage mortality, mainly in first year

\begin{tabular}{|c|c|c|c|c|c|c|c|}
\hline & \multirow{2}{*}{$\begin{array}{l}\text { MacMahon } \\
\text { et al. } \\
\text { (I953) }\end{array}$} & \multicolumn{2}{|l|}{ Carlgren } & \multirow{2}{*}{$\begin{array}{l}\text { Hay } \\
(1966)\end{array}$} & \multirow{2}{*}{$\begin{array}{l}\text { Mitchell } \\
\text { et al. } \\
(I 97 I)\end{array}$} & \multirow[t]{2}{*}{ Mean ${ }^{\star}$} & \multirow{2}{*}{$\begin{array}{l}\text { Usual } \\
\text { range }\end{array}$} \\
\hline & & (I959) & (I969) & & & & \\
\hline \multicolumn{8}{|l|}{ Ventricular septal defect } \\
\hline $\begin{array}{l}\text { Large } \\
\text { Small }\end{array}$ & 44 & \}$^{40}$ & $\left.\begin{array}{r}44 \\
0\end{array}\right\}$ & $16 \cdot 5$ & 10.5 & 36 & $20-45$ \\
\hline Atrial septal defect group & 77 & 29 & 21 & 45 & 13 & 36 & $25-45$ \\
\hline Persistent ductus arteriosus & 42 & 19 & I I & $34 \cdot 5$ & 31 & 23 & $20-30$ \\
\hline $\left.\begin{array}{l}\text { Coarctation, preductal } \\
\text { Coarctation, postductal }\end{array}\right\}$ & 84 & 79 & 53 & 55 & $\left\{\begin{array}{r}85 \\
9\end{array}\right\}$ & $6 I$ & $55-70$ \\
\hline Aortic stenosis & 25 & 46 & 28 & 18 & 0 & 29 & $20-35$ \\
\hline Pulmonary stenosis & 69 & 25 & 19 & 7 & 10.5 & 24 & $20-30$ \\
\hline Fallot's tetralogy & $4 \mathrm{I}$ & 45 & 60 & 68 & 25 & 53 & $45-60$ \\
\hline Transposition & 92 & 83 & 96 & 85 & 45 & 89 & $85-90$ \\
\hline Truncus & 94 & 80 & - & 83 & 67 & 86 & $80-90$ \\
\hline Others & 79 & 44 & 52 & 80 & - & 57 & $50-70$ \\
\hline All with diagnosis & $372+$ & $322+$ & 450 & 314 & 459 & 1917 & \\
\hline
\end{tabular}

* In calculating means the figures of MacMahon et al. have been reduced by one-third except for ventricular septal defect, transposition, and truncus, and those of Mitchell omitted (see text).

† In 26I infants of MacMahon et al. (1953) and in 47 of Carlgren (1959) no firm diagnosis was made. In later series this was unusual. 
ranging from 90 to 25 per cent in different cardiac malformations. It is outside my personal experience, but Landtman (197I) has painted a gloomy picture of 777 children dying in hospital before they were 16: one-third died in their first week, another third within three months, and 85 per cent in their first year. The rate of mortality falls in an exponential curve, very steeply even when drawn on a logarithmic scale (Fig.).

Half showed asphyxia at birth; over half had obvious cyanosis, but often due to noncardiac causes (Watson, I972). Nearly half had other noncardiac malformations also, more than one in many. These often cause death and call for careful consideration whether curing the heart, if possible, is really in the child's interest.

Advances in treatment, Mustard's operation, Rashkind's balloon atrial septostomy, and facilities at special units, have saved many lives. Watson (1972) thinks mortality at some centres may now be nearer 20 to 30 per cent in the first month. The much lower mortalities of Mitchell et al. (197I) support this and have, therefore, been excluded in calculating means and ranges in Table 4, because my subject is the natural history, i.e. what happened before modern advances improved their outlook.

Early mortality of individual malformations is shown for five series - MacMahon et al. (1953), Carlgren (1959, 1969), Hay (1966), and Mitchell et al. (197I). The length of follow-up varied from 3 to 16 years, but the first year's mortality is so high as to make the other years relatively unimportant.

The different series agree well for five conditions with the highest mortality. The very high rates for transposition $(89 \%)$ and truncus arteriosus $(86 \%)$ might be expected from their rarity in older patients. The high rate for aortic coarctation $(6 \mathrm{I} \%)$ is due to the infantile (preductal) group where Mitchell et al. (197I) found a neonatal mortality of 80 per cent. Nearly all die within a year and Abbott's necropsies gave a mean age at death of only 2 months. For the adult (postductal) type Mitchell found the mortality to be only 9 per cent, so these two should always be distinguished in statistics. 'Other cardiac malformations', which often include those with two malformations as well as less common ones, have a high mortality rate $(57 \%)$. The fifth condition is Fallot's tetralogy with a mortality of about 53 per cent.

Mortality rates of MacMahon et al. were generally about 56 per cent higher than rates of Carlgren and of Hay though if their deaths are expressed as percentages of total births instead of those with diagnosed malformations, they come into line with the others. In calculating a mean mortality their estimates have, therefore, been reduced by one-third.
Mortality rates of different authors vary so much for the remaining five malformations that I have no confidence of the order in which they should be placed. They are all, however, in the region of 23 to 36 per cent. Probably the rate is higher in ventricular and atrial septal defects (both about $36 \%$ ) than in aortic stenosis $(29 \%)$ and lower in pulmonary stenosis $(24 \%)$ and persistent ductus arteriosus $(23 \%)$.

Special difficulties about ventricular septal defects were described by Hay (1966) and grasped firmly by Carlgren (1969) who divided them into 'large ventricular septal defect' with a mortality of about 40 per cent and 'small ventricular septal defect' with no mortality and a strong tendency to close. I believe this is the true position (Campbell, 1971) and that two groups must be distinguished, as with aortic coarctation.

Children at paediatric clinics are not comparable because many have died before reaching them, but mortality is still high. Keith et al. (1958) state that all with aortic atresia die in the first few months. Of those with transposition 85 per cent, and of those with pulmonary atresia 78 per cent, died in the first 6 months. Of those with truncus arteriosus over 70 per cent and of those with tricuspid atresia 66 per cent died in the first year. Eighty per cent of those with preductal coarctation but only 20 per cent with postductal coarctation died in the first year. The mortality for Fallot's tetralogy was 20 per cent mainly in the first 2 years. Their deaths from ventricular septal defect are combined with other reported ones. Of 138 deaths, the percentages were 27 in the first year, another 27 in the rest of the first decade, 17 in the second decade, 9 in the third, 12 in the fourth, and 8 in later decades. Their mortalities for aortic stenosis (10\%), atrial septal defect $(8 \%)$, pulmonary stenosis $(8 \%)$, and persistent ductus arteriosus (only $2 \%$ with congestive failure and I2 \% with significant symptoms) were much lower than for unselected infants followed from birth.

Ober and Moore (1955), among 9 stillbirths and $9 \mathrm{I}$ infants dying during the first month $70 \%$ in the first week) from malformations of the heart, found 27 had transposition, I9 had ventricular septal defect, I2 had cor biloculare or triloculare, II had coarctation, 7 had fibroelastosis, 6 had atrial septal defect, 4 had truncus arteriosus, and 4 had Fallot's tetralogy (these accounting for $90 \%$ ).

\section{Incidence in later life}

\section{Paediatric clinics and schools}

The heavy early mortality makes cardiac malformations less common among children than among infants at birth. During the first year the neonatal 
TABLE 5 Percentage distribution of different malformations in children

\begin{tabular}{|c|c|c|c|c|c|c|c|c|}
\hline & \multicolumn{3}{|c|}{ In paediatric clinics } & \multicolumn{3}{|c|}{ In schoolchildren } & \multirow[t]{2}{*}{ Mean } & \multirow{2}{*}{$\begin{array}{l}\text { Usual } \\
\text { range }\end{array}$} \\
\hline & $\begin{array}{l}\text { Keith } \\
\text { et al. }(1958)\end{array}$ & $\begin{array}{l}\text { Nadas } \\
(1963)\end{array}$ & $\begin{array}{l}\text { Stuckey } \\
\text { (1954) }\end{array}$ & $\begin{array}{l}\text { Hay } \\
(1963)\end{array}$ & $\begin{array}{l}\text { Mustacchi } \\
\text { et al. }(1963)\end{array}$ & $\begin{array}{l}\text { Morton and } \\
\text { Huhn (1966) }\end{array}$ & & \\
\hline Ventricular septal defect & 25 & 20 & 24 & 28 & 44 & 12 & 25 & $20-28$ \\
\hline Persistent ductus arteriosus & 17 & $12 \cdot 5$ & $17 \cdot 5$ & 14 & Io & II & 14 & $12-17$ \\
\hline Atrial septal defect & 7 & $14^{\star}$ & II & $15^{\star}$ & 12 & 20 & I3.5 & II -15 \\
\hline Pulmonary stenosis & 7 & 12 & 9 & 17 & 14 & 20 & $12 \cdot 5$ & $9-17$ \\
\hline Aortic stenosis & 4 & 6 & 3 & 12 & 6 & 17 & 8 & $6-12$ \\
\hline Fallot's tetralogy & II & 14 & $\begin{array}{l}3 \\
15\end{array}$ & 4 & 0 & 4 & $8 \cdot 5$ & $4-1 I$ \\
\hline Coarctation & 6 & 5 & 4 & $\begin{array}{l}4 \\
2 \cdot 5\end{array}$ & 8 & 8 & $5 \cdot 5$ & $4-8$ \\
\hline Transposition & 8 & 4 & 5 & 0 & & & 3 & - \\
\hline Truncus & I & 工 & 1.5 & 0 & 6 & 8 & - & - \\
\hline Tricuspid atresia & 3 & $\mathbf{I}$ & 2.5 & 0.3 & & & - & - \\
\hline All others & II & $11 \cdot 5$ & $7 \cdot 5$ & $7 \cdot 2$ & & & I0 & $8-I I$ \\
\hline No. of cases & $t$ & 2786 & 426 & 291 & 244 & 80 & & \\
\hline
\end{tabular}

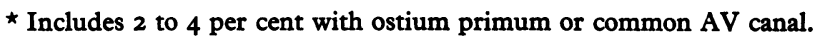

† A large number but exact figure not given.

mortality will reduce their incidence from about 8 to 5 per 1000. Others will die before school age, reducing it further. Morton and Huhn (1966) found 4.7 per 1000, but Hay (1966) only $2 \cdot 2$, and Mustacci et al. (1963) only 2 per 1000 .

There are also changes in their relative frequency. Fallot's tetralogy becomes much less common and other cyanotic malformations become rare. Figures from three paediatric clinics (Keith et al., 1958; Nadas, 1963; Stuckey, 1954) and from three studies of schoolchildren (Hay, I963, in Liverpool; Mustacci et al., 1963, in San Francisco; and Morton and Huhn, 1966, in southern U.S.A.) are shown in Table 5.

The findings differ so much that some estimates can hardly be correct. Certainly ventricular septal defect is the most common (between 20 and $28 \%$ ). Next comes persistent ductus arteriosus (about
14\%), atrial septal defect (13.5\%), and pulmonary stenosis (12.5\%). These are followed by aortic stenosis and Fallot's tetralogy (about $8 \%$ ) and aortic coarctation $(4-8 \%)$. There is no consistent difference between paediatric clinics and schoolchildren except that Fallot's tetralogy and other cyanotic conditions are much less common in schoolchildren. Perhaps atrial septal defect and aortic and pulmonary stenosis are commoner in children attending school and persistent ductus arteriosus less so, possibly because of successful operations.

\section{Children and adults}

Four series (Campbell, 1953; Blumenthal, 1953; Wood, I956; Schrire, I963) are used for this group (Table 6). There were many children, but few under 3 years, and many young and some older adults.

TABLE 6 Percentage distribution of different malformations in children and adults

\begin{tabular}{llllll}
\hline & $\begin{array}{l}\text { Campbell } \\
(1953)\end{array}$ & $\begin{array}{l}\text { Wood } \\
(1956)\end{array}$ & $\begin{array}{l}\text { Schrire } \\
(1963)\end{array}$ & $\begin{array}{l}\text { Blumenthal } \\
(1953)\end{array}$ & Average \\
\hline Ventricular septal defect & 15 & $12 \cdot 3$ & 22 & $17 \cdot 7$ & 17 \\
Atrial septal defect & 16 & $20 \cdot 5$ & 17 & $16 \cdot 5$ & $17 \cdot 5$ \\
Persistent ductus arteriosus & $15 \cdot 5$ & 15 & 16 & 12 & $14 \cdot 5$ \\
Coarctation & 8 & 9 & 6 & 6 & 7 \\
Aortic stenosis & 5 & 3 & $4 \cdot 5$ & 7 & 5 \\
Pulmonary stenosis & 15 & 16 & 9 & 11 & 13 \\
Fallot's tetralogy & $15 \cdot 5$ & $12 \cdot 7$ & 12 & $18 \cdot 3$ & $14 \cdot 5$ \\
Transposition & 2 & 1 & 2 & $(1)$ & $1 \cdot 5$ \\
Tricuspid atresia & 1 & $1 \cdot 5$ & $1 \cdot 5$ & 2 & $1 \cdot 5$ \\
Various & 7 & 9 & 10 & $8 \cdot 5$ & $8 \cdot 5$ \\
& & & & &
\end{tabular}


Mine were II30 patients seen in I947-5I and reviewed again in 1957. Necropsies were available in I2O and many had undergone operations and special investigations.

The results show that the predominance of ventricular septal defect has gone, probably because of the numbers that have closed spontaneously. Atrial septal defect (17.5\%), ventricular septal defect $(17 \%)$, and persistent ductus arteriosus ( $14.5 \%)-$ the three main malformations with left-to-right shunts - are now about equally common. Fallot's tetralogy (14.5\%) comes next but is almost certainly overweighted because of the great interest when subjects of any age could for the first time have surgical treatment. Pulmonary stenosis (13\%) comes next.

Aortic coarctation $(7 \%)$ and aortic stenosis $(5 \%)$ are about half as common as the groups already mentioned. These account for nearly 90 per cent of all malformations, transposition and tricuspid atresia (each $\mathrm{I} \cdot 5 \%$ ) and various other malformations $(8.5 \%)$ forming the remainder.

Atrial septal defect is the only condition where I know a survey of its incidence in the general adult (I5-65 years) population has been carried out. Seldon, Rubinstein, and Fraser (1962) in Australia found it to be just under 0.2 per 1000 . At birth it should be 0.8 , and neonatal mortality soon reduces this to 0.5 per 1000. My calculations make it 0.45 at 20 and 0.3 per 1000 at 30 years, this agreeing reasonably with the Australian observations.

So far we have been dealing with observed incidence of different cardiac malformations among different age groups. If the incidence at birth and the mortality are known, we should be able to calculate reasonably similar incidences.

\section{Calculated incidences in children and adults}

These calculations are shown in Table 7. Figures in the second column are taken from mean incidence at birth in Table 2. Those in the third column are calculated from the neonatal mortality (Table 4) and those in the fourth and fifth columns are from my calculated mortality rates for the first six conditions, but are rougher estimates for the others.

Survivors means those living with the defect still present, i.e. those where a persistent ductus or ventricular septal defect has closed spontaneously are excluded. The figures in parentheses show the calculated percentage incidence at various ages. The last column shows the observed percentage incidence of the different cardiac malformations taken from the mean values of the four authors given in Table 6.

The calculated and observed incidences agree much more closely than might have been expected. The only real differences are that the observed figures for Fallot's tetralogy and transposition are much too high and for aortic stenosis only about half of what my calculations suggest. The former are easily explained, as before 1953-63, when the four series were reported, cyanotic patients were attending hospital in such large numbers in the hopes of having operations. The explanation for the latter is not obvious but the calculated figure seems likely to be nearer to the truth. My calculations were completed before I looked back at Table 6 .

\section{Sex distribution of cardiac malformations}

Some differences have been recognized a long time. At necropsies, Abbott (1936) found the male inci-

TABLE 7 Calculated incidences in children and adults

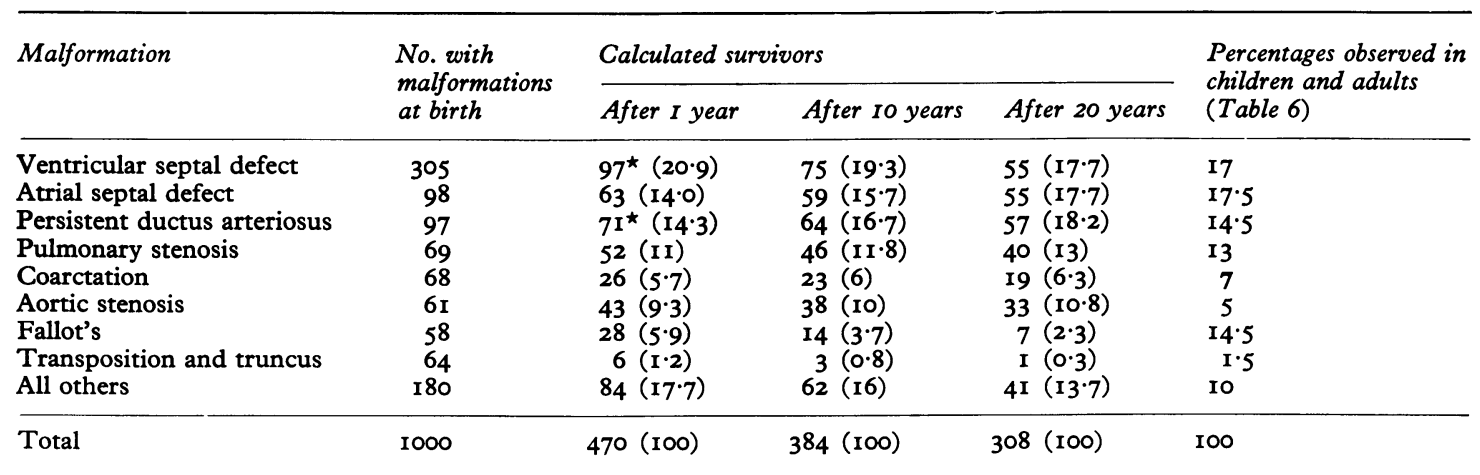

$\star$ Those where a persistent duct or ventricular septal defect has closed spontaneously are excluded. 
TABLE 8 Sex incidence at birth and later

\begin{tabular}{llll}
\hline Malformation & \multicolumn{3}{l}{ Percentage of male subjects } \\
\cline { 2 - 4 } & $\begin{array}{l}\text { At } \\
\text { birth }\end{array}$ & $\begin{array}{l}\text { In } \\
\text { children† }\end{array}$ & $\begin{array}{l}\text { In adults and } \\
\text { children, most } \\
\text { over } 5 \text { years }\end{array}$ \\
\hline & & & \\
\hline Persistent ductus & & & 30 \\
$\quad$ arteriosus & 37 & 35 & 35 \\
Atrial septal defect & 51 & 45 & 49 \\
Ventricular septal defect & 54 & 52 & 48 \\
Pulmonary stenosis & 55 & 54 & 57 \\
Fallot's tetralogy & 57 & 56 & 76 \\
Aortic stenosis & 59 & 62 & 72 \\
Coarctation & 60 & 66 & - \\
Transposition & 67 & 66 & 78 \\
Bicuspid aortic valves & & - & \\
$\quad$ (all ages) & - & - &
\end{tabular}

* These are based on 2263 births from MacMahon et al. (1953), Carlgren (1959, 1969), Hay (1966), and Landtman (197I).

† Mainly from Keith et al. (1958) (see text).

† From 5 I 5 I patients (see text).

dence lower in persistent ductus and higher in aortic coarctation, bicuspid aortic valves, and most cyanotic conditions. Incidence at birth is shown in the first column of Table 8, based on 2263 subjects of five series which agree fairly well.

Persistent ductus is the only common condition with more girls than boys at birth, the male incidence being only 37 per cent. Atrial septal defect occurs in equal numbers of girls and boys. Male excess is slight, but probably not significant, in ventricular septal defect $(54 \%)$ and pulmonary stenosis $(55 \%)$. In Fallot's tetralogy $(57 \%)$ it is not much higher but probably significant as it persists at all ages.

For all other common conditions, male incidence is significantly higher, for aortic stenosis ( $59 \%)$, aortic coarctation $(60 \%)$, for truncus arteriosus $(60 \%)$, transposition $(67 \%)$, tricuspid atresia (68\%), and for bicuspid aortic valves $(78 \%)$.

The distribution in children, including some infants, is shown in the second column, from some children of Schrire (1963) but mainly from Keith et al. (1958). Unfortunately they gave no figures for pulmonary stenosis and ventricular septal defect, so these estimates use my smaller number of children under I5 years. Changes are generally small but probably significant as they continue in the same direction.

The third column shows the sex distribution among 515I patients at medical clinics, adults and children, mostly over 5 years (Campbell, 1968b, c, 1969, I970a, b, 197I). Persistent ductus and atrial septal defect show a progressive fall in the male incidence down to 30 to 35 per cent. Ventricular septal defect shows a much smaller fall to only 49 per cent. But if the ventricular septal defect patients are grouped in the fourth and later decades, there are $35(39 \%)$ men and $54(6 \mathrm{r} \%)$ women, while in the first three decades the numbers are 267 male and 250 female patients. Brotmacher and Campbell (1958) found that among 180 ventricular septal defect patients 57 per cent of those born in 1940 or later were boys, but only 26 per cent of those born before 1940 were men. They thought boys became cyanotic earlier and died earlier than girls, perhaps because they were less ready to reduce their activity. This could also be the explanation for the excess of women with atrial septal defect at older ages, but I have no direct evidence of a higher mortality among boys and men with persistent ductus arteriosus.

Pulmonary stenosis is probably the only common cardiac malformation, with an equal sex incidence at birth and through life. Its incidence in Table 8 is similar to that for ventricular septal defect but I have no evidence that it falls at later ages. In fact, most elderly patients I remember with pulmonary stenosis were men, this contrasting with atrial and ventricular septal defect.

In Fallot's tetralogy, transposition, and bicuspid aortic valves, the male excess continues at about the same level. In aortic stenosis and coarctation it even increases from about 60 to 76 and 72 per cent.

We need more information about sex incidence in miscarriages and stillbirths. If a differential prenatal mortality does not explain the differential sex incidence at birth, this might provide a clue to their aetiology.

Most people know that women now live longer than men, with a mean age of about 73 instead of 68 years. But in developing countries, men still live longer than women to about 4I instead of 38 years. Perhaps less generally known is that for very many centuries records show men dying at means about 25 to 29 and women at 18 to 26 years (Russell and Russell, 1972).

This greater toughness of women in modern times is illustrated by Suoninen (197I) who found that operative mortality in boys was twice as high as in girls with persistent ductus, coarctation, or Fallot's tetralogy. This might explain conditions where the proportion of women to men increases with age, but would make it more difficult to understand those where male preponderance increases. I have no direct evidence of a higher mortality in girls with coarctation or aortic stenosis, but it is hard to see any other explanation.

The increasing number of men with aortic stenosis is probably due to its development on bi- 
cuspid aortic valves, four times as common in men as in women. Polani has suggested to me that the higher mortality in girls with coarctation might be due to the association with Turner's syndrome, which has an incidence of about $I$ in 3000 . Assuming half these girls also have coarctation, and that this has an incidence at birth of $I / 2000$ in both sexes, it would be made up as follows - I/6000 girls with Turner's syndrome and coarctation, I/3000 girls with coarctation alone, and I/2000 boys. The neonatal mortality is high; if it continued high for girls with coarctation and Turner's syndrome, and if half of them died in the first decade, this might explain the increasing male frequency. Campbell and Polani (I96I) have suggested a possible but purely speculative reason why there may be more girls with persistent ductus and more boys with coarctation.

\section{References}

Abbott, Maude E. (1936). Atlas of Congenital Cardiac Disease. American Heart Association, New York.

Blumenthal, S. (1953). The incidence of congenital cardiac malformations. Transactions of the American College of Cardiology, 3, 209.

Brotmacher, L., and Campbell, M. (1958). The natural history of ventricular septal defect. British Heart fournal, 20, 97.

Brown, J. W. (1939). Congenital Heart Disease. John Bale Medical Publications, London.

Caddell, J. L., and Connor, D. H. (1966). Congenital heart disease in Ugandan children. British Heart fournal, 28, 766.

Campbell, M. (1953). The frequency of different types of congenital heart disease. British Heart fournal, 15, 462.

Campbell, M. (1968a). Natural history of persistent ductus arteriosus. British Heart fournal, 30, 4.

Campbell, M. (1968b). Natural history of congenital aortic stenosis. British Heart fournal, 30, 514.

Campbell, M. (I968c). Calcific aortic stenosis and congenital bicuspid aortic valves. British Heart fournal, 30, 606 .

Campbell, M. (1968d). The incidence and later distribution of malformations of the heart. In Paediatric Cardiology, p. 71. Ed. by Hamish Watson. Lloyd-Luke (Medical Books), London.

Campbell, M. (1969). Natural history of congenital pulmonary stenosis. Aloisio Conderelli Festschrift Romae, p. 69.

Campbell, M. (1970a). Natural history of coarctation of the aorta. British Heart fournal, 32, 633.

Campbell, M. (1970b). Natural history of atrial septal defect. British Heart fournal, 32, 820.

Campbell, M. (1971). Natural history of ventricular septal defect. British Heart fournal, 33, 246.

Campbell, M., and Deuchar, D. C. (1954). The left-sided superior vena cava. British Heart fournal, 16, 423.

Campbell, M., and Polani, P. E. (I96I). The aetiology of coarctation of the aorta. Lancet, $1,463$.

Carlgren, L. E. (1959). The incidence of congenital heart disease in children born in Gothenberg, 1941-50. British Heart fournal, 21, 40.

Carlgren, L. E. (1969). The incidence of congenital heart disease in Gothenberg. Bulletin of the Association of European Paediatric Cardiologists, 5, 2.
Carter, C. O. (196I). Congenital abnormalities. In Conference on Clinical Aspects of Genetics at the Royal College of Physicians of London, p. 30. Ed. by F. Avery Jones. Pitman Medical Publishing Co., London.

Gupta, B., and Antia, A. U. (1967). Incidence of congenital heart disease in Nigerian children. British Heart fournal, 29, 906.

Harris, L. E., and Steinberg, A. G. (1954). Abnormalities observed during the first six days of life in 8716 live-born infants. Pediatrics, 14, 314.

Hay, John (1963). Personal communication. Subsequently published in the City of Liverpool Education Committee's report on the work of the school health service for 1963 by A. R. Semple.

Hay, J. D. (1966). Population and clinic studies of congenital heart disease in Liverpool. British Medical fournal, 2, 661.

Hoffman, J. I. E. (1968). Natural history of congenital heart disease. Circulation, 37, 97.

Keith, J. D., Rowe, R. D., and Vlad, P. (1958). Heart Disease in Infancy and Childhood. MacMillan, New York.

Kerrebijn, K. F. (1966). Incidence in infants and mortality from congenital malformations of the circulatory system. Acta Paediatrica Scandinavica, 55, 316.

Lamy, M., and Frezal, J. (1960). The frequency of congenital malformations, p. 34. In First International Conference on Congenital Malformations, London, fuly 18-22. J. B. Lippincott, Philadelphia and Montreal.

Landtman, B. (1965). Epidemiological aspects of congenital heart disease. Acta Paediatrica Scandinavica, 54, 467.

Landtman, B. (1971). Clinical and morphological studies in congenital heart disease: review of 777 cases. Acta Paediatrica Scandinavica, Suppl. 213.

McIntosh, R., Merritt, K. K., Richards, M. R., Samuels, M. H., and Bellows, M. T. (1954). The incidence of congenital malformations: a study of 5964 pregnancies. Pediatrics, I4, 505 .

McKeown, T., and Record, R. G. (1960). Malformations in a population observed for five years after birth. In Ciba Foundation Symposium on Congenital Malformations, p. 2. Ed. by G. E. W. Wolstenholme and C. M. O'Connor. Churchill, London.

MacMahon, B., McKeown, T., and Record, R. G. (1953). The incidence and life expectation of children with congenital heart disease. British Heart fournal, 15, 21.

Michaëlsson, M. (1964). Specialutredning och operation av medfödda hiartfel och forvarvade klaffel. Svenska Läkartidningen, 61, 2370.

Mitchell, S. C. Korones, S. B., and Berendes, H. W. (I97I). Congenital heart disease in 56,109 births; incidence and natural history. Circulation, 43, 323.

Morton, W. E., and Huhn, L. A. (I966). Epidemiology of congenital heart disease. Fournal of the American Medical Association, 195, 1107.

Muir, C. S. (1960). Incidence of congenital heart disease in Singapore. British Heart fournal, 22, 243.

Mustacchi, P., Sherins, R. S., and Miller, M. J. (1963). Congenital malformations of the heart and the great vessels: prevalence, incidence, and life expectancy in San Francisco. Fournal of the American Medical Association, 183, 24I.

Nadas, A. S. (1963). Pediatric Cardiology, 2nd ed. W. B. Saunders, Philadelphia and London.

Neel, J. V. (1958). A study of major congenital defects in Japanese infants. American fournal of Human Genetics, 10, 398.

Ober, W. B., and Moore, T. E. (1955). Congenital cardiac malformations in the neonatal period. New England fournal of Medicine, 253, 271 . 
Richards, M. R., Merritt, K. K., Samuels, M. H., and Langmann, A. G. (1955a). Congenital malformations of the cardiovascular system in a series of 6053 infants. Pediatrics, 15, 12.

Richards, M. R., Merritt, K. K., Samuels, M. H., and Langmann, A. G. (I955b). Frequency and significance of cardiac murmurs in the first year. of life. Paediatrics, 15, 169.

Rose, V., Boyd, A. R. J., and Ashton, T. E. (1964). Incidence of heart disease in children in the city of Toronto. Canadian Medical Association fournal, 91, 95.

Russell, C., and Russell, W. M. S. (1972). The life span of men and women. Guy's Hospital Gazette, 86, 30.

Schrire, V. (1963). Experience with congenital heart disease at Groote Schuur Hospital, Cape Town. South African Medical fournal, 37, 1175.

Seldon, W. A., Rubinstein, C., and Fraser, A. A. (1962). The incidence of atrial septal defects in adults. British Heart Fournal, 24, 557.

Smithells, R. W. (1968). Incidence of congenital abnormalities in Liverpool, 1960-64. British fournal of Preventive and Social Medicine, 22, 36.
Suoninen, P. (197I). Physical growth of children with congenital heart disease. Acta Paediatrica Scandinavica, Suppl. 225.

Stuckey, D. (1954). The pattern of congenital heart disease in infancy and childhood. Medical fournal of Australia, 2, 433.

Taussig, H. B. (1936). The clinical and pathological findings in congenital malformations of the heart due to defective development of the right ventricle associated with tricuspid atresia or hypoplasia. Bulletin of the fohns Hopkins Hospital, 59, 435 .

Watson, H. (1972). The early detection of congenital malformations of the heart. British Heart fournal, 34, 37.

Wauchope, Gladys M. (1928). The clinical importance of variations in the number of cusps forming the aortic and pulmonary valves. Quarterly fournal of Medicine, 21, 383.

Wood, P. (1956). Diseases of the Heart and Circulation, 2nd ed. Eyre and Spottiswoode, London.

Requests for reprints to Dr. Maurice Campbell, 47 Arkwright Road, Hampstead, London N.W.3. 